\title{
Events Due to Snowblower Use Seen in US Emergency Departments From 2003 Through 2018
}

Randall T. Loder ${ }^{1}$, Dhruv Solanki ${ }^{2}$

1. Orthopaedic Surgery, Riley Hospital for Children, Indianapolis, USA 2. Orthopaedic Surgery, Indiana University School of Medicine, Indianapolis, USA

Corresponding author: Randall T. Loder, rloder@iupui.edu

\section{Abstract \\ Objective}

To comprehensively analyze emergency department (ED) visits associated with snowblower use in the United States.

\section{Methods}

Data on National Electronic Injury Surveillance System ED visits due to snow blowers from 2003 through 2018 were analyzed by age, sex, diagnosis, anatomic location of the injury, and year, month, or weekday. The mechanism of injury and alcohol use were noted. Statistical analyses were performed, accounting for the weighted, stratified nature of the data.

\section{Results}

There were an estimated 91,451 patients with an average age of 51 years; $91.2 \%$ were male. Amputation, fracture, or laceration accounted for 43,524 (47.6\%) of the ED visits. The mechanism of injury was placing the hand into the chute (44.5\%), a fall/slip (13.3\%), medical events (6.1\%), and miscellaneous (33.8\%). Most (68.9\%) occurred at home. Alcohol was rarely involved (0.4\%). There were 648 deaths; 647 were due to cardiac events. The five major injury diagnoses were fracture (25.9\%), laceration (20.2\%), strain/sprain (15.0\%), amputation (11.2\%), and contusion/abrasion (10.2\%); $99.8 \%$ of the amputations involved fingers. The incidence of ED snowblower visits was 1.845 per 100,000 US population with no change over time. There was a general correlation between the number of visits and the annual snow cover.

\section{Conclusions}

Ample opportunity for injury prevention exists, as there was no change in the incidence over time. Cardiac events accounted for essentially all of the deaths.

Review began 10/03/2020 Review ended 11/24/2020 Published 12/01/2020

\section{(c) Copyright 2020}

Loder et al. This is an open access article distributed under the terms of the Creative Commons Attribution License CC-BY 4.0., which permits unrestricted use, distribution, and reproduction in any medium, provided the original author and source are credited.
Categories: Emergency Medicine, Orthopedics, Environmental Health

Keywords: amputation, fracture, cardiac, medical, snowcover, snowblower

\section{Introduction}

Power snow blowers allow for easier, quicker snow removal at homes and businesses. However, they are potentially dangerous and can result in significant injury. Most studies of snowblower injuries discuss those sustained when placing the hand into the chute, resulting in lacerations, fractures, and, frequently, amputations [1-13]. However, other injuries can also occur such as being hit by a missile ejected from the chute, slipping/falling while using the snow blower, and medical issues such as shortness of breath and cardiac events (myocardial infarction/cardiac arrest). Cardiac events have been associated with snow shoveling [14-21] with four case reports involving snow blowers [19]. In that study, four of 36 cardiac deaths associated with snow removal occurred while using a snow blower [19]. There is very little literature reviewing the whole scope of injury associated with snow blowers. It was the purpose of this study to analyze all types of injuries and medical events associated with snowblower use presenting to emergency departments (EDs) in the United States.

\section{Materials And Methods}

\section{Data source}

The data for this study were obtained from the National Electronic Injury Surveillance System (NEISS). This database is in the public domain and can be found at www.cpsc.gov/library/neiss.html. The NEISS is a stratified, weighted dataset managed by the US Consumer Product Safety Commission (USCPSC), which collects injury data from $\sim 100$ hospitals in the US and its territories with an ED and designed to study 
injuries due to consumer products. Further details regarding the acquisition of the NEISS data and guidelines for the use of such data can be accessed from its web site.

Detailed data for ED visits for the period 2003 through 2018 due to snow blowers/snow throwers (NEISS product code 1406) was downloaded from the NEISS website and analyzed by age, sex, diagnosis, race, anatomic location of the injury, and year/month/weekday of the ED visit. Race was classified as White, Black, Amerindian (Hispanic and Native American), and Asian [22]. The use of this publicly available, de-identified data was considered exempt by our local Institutional Review Board.

The narrative comments for each case were further analyzed to review other parameters. The mechanism of injury was classified into six major groups: 1) put/reached hand into snowblower chute, 2) fell/slipped while using the snow blower, 3) run over by the snow blower, 4) other encounters, 5) missiles projected from the snow blower (eg. snow, ice, sand), and 6) medical issues (eg, syncope, shortness of breath, angina/cardiac arrest). Examples of other encounters are soreness/pain after using the snow blower, injuries while moving/repairing the snow blower, etc. Alcohol involvement was determined by searching the detailed comments with the FIND command in Microsoft Excel ${ }^{\mathrm{TM}}$ (Microsoft ${ }^{\circledR}$ Office 365, Microsoft Corporation, Redmond, WA). The terms used to search for alcohol were: alcohol, EtOH, intoxicated, drinking, drank, drunk, club, ethanol, saloon, tavern, liquor, booze, beer, whiskey, brandy, rum, vodka, scotch, tequila, wine, sake, champagne, and cognac.

\section{Statistical analysis}

Statistical analyses were performed with SUDAAN 11.0.01 ${ }^{\mathrm{TM}}$ software (RTI International, Research Triangle Park, North Carolina, 2013), which accounts for the weighted, stratified nature of the data. The estimated number of injuries/ED visits is calculated, along with $95 \%$ confidence intervals (CIs) of the estimate. When the actual number of patients $(n)$ is $<20$, the estimated number $(N)$ becomes unstable and should be interpreted with caution; thus, we report both $\mathrm{n}$ and $\mathrm{N}$. The annual incidence of ED visits for assault was calculated using US Census Bureau data. Analyses between groups of continuous data were performed with the t-test (two groups) or analysis of variance (ANOVA) (three or more groups). Differences between groups of categorical data were analyzed by the chi-square test. $p<0.05$ was considered to be statistically significant.

\section{Results}

There were 1,921 actual ED visits for snowblower injuries, or an estimated $91,451(79,800$ - 104,894) over the time span of the study. These $91,451 \mathrm{ED}$ visits represent $0.041 \%$ of all estimated consumer product related ED $(220,819,326)$ visits in the NEISS data base over the same time span. The average age was 51.0 years $(49.7$, $52.1)$ and the median age was 50.9 years (interquartile range (39.1, 62.5 years)). Most of the patients were male $(83,409(81,382$ - 85,059) - 91.2\%) and released from the ED $(79,185$ (76,083 - 81,699) - 86.6\%). Race was known in 63,752 of the patients and was overwhelmingly White $(93.8 \%)(59,814-(57,026-61,489))$. The mechanism of injury was known in 89,658 (98.0\%) of the patients. The patient placed the hand into the chute in $44.5 \%(40,692(35,611-48,112))$, other mechanisms in $31.5 \%(28,835(25,277-33,873))$, a fall/slip in $13.3 \%(12,172(10,535-14,568))$, medical events in $6.1 \%(5,580(4,563-7,078))$, a missile/projectile in $1.3 \%(1,230(796-1,975))$, and being run over by the snow blower in $1.0 \%(871-(521-1,500))$. The incident location was at the home in $68.9 \%(62,989(49,722-73,554))$, unknown in $29.3 \%(26,780(16,278-40,412))$, with those occurring on the street, other public property, school, and recreation/sporting facilities accounting for the remaining $1.9 \%$. Alcohol was involved in $0.4 \%$ (354 (183 - 695)) of the patients.

\section{Medical events}

Patients with medical events (Table 1$)$ were older than those with injuries $(60.1$ vs 50.4 years - $\mathrm{p}<10-4)$. There were an estimated 648 deaths; all occurred in those with medical events. A cardiac event is a subset of all medical events. Cardiac events were identified when the narrative comments included the following terms: myocardial infarction (MI), cardiac, arrhythmia, angina, cardiovascular disease, heart attack. Those with a cardiac event were again older (68.1 vs 50.7 years $-\mathrm{p}<10-4)$ (Table 2) than those with other events and all were male. There was one death in the non-cardiac group. The narrative comments of that case stated the patient was a 76-year old male who went into his home due to shortness of breath after using a snow blower and was dead on arrival. This may or may not have been a cardiac event as well. 


\section{Cureus}

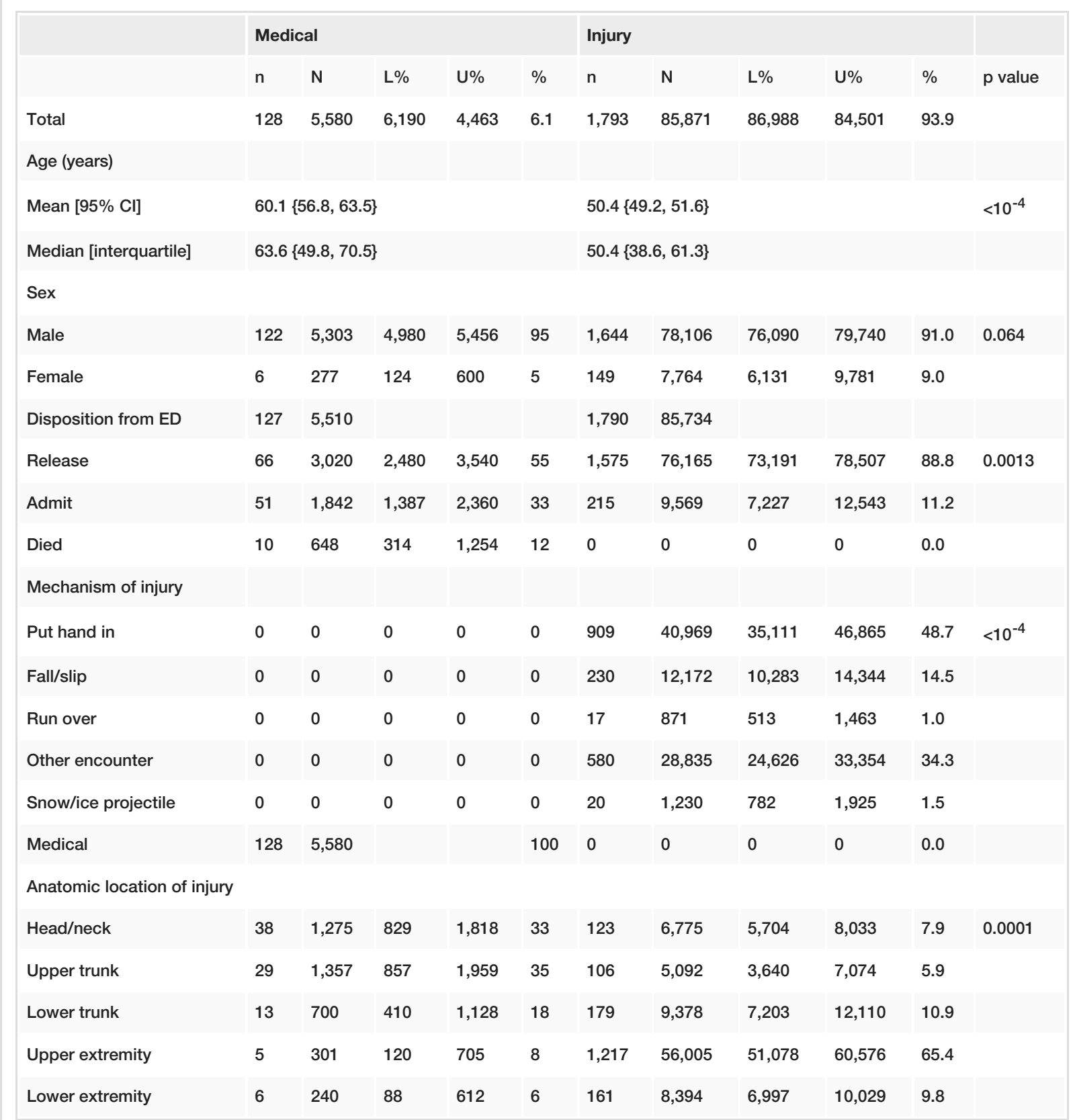

\section{TABLE 1: ED visits associated with snow blowers by a medical event or injury}

$\mathrm{n}=$ actual number of ED visits, $\mathrm{N}=$ estimated number of ED visits, $\mathrm{L} \%=$ lower $95 \%$ confidence interval of the estimate, $U \%=u p p e r 95 \%$ confidence interval of the estimate 


\section{Cureus}

\begin{tabular}{|c|c|c|c|c|c|c|c|c|c|c|c|}
\hline & \multicolumn{5}{|c|}{ Cardiac event } & \multicolumn{5}{|c|}{ No cardiac event } & \multirow[b]{2}{*}{$p$ value } \\
\hline & $\mathrm{n}$ & $\mathrm{N}$ & $\mathrm{L} \%$ & $\mathrm{U} \%$ & $\%$ & $\mathrm{n}$ & $\mathrm{N}$ & L\% & U\% & $\%$ & \\
\hline & 27 & 1,338 & 2,030 & 878 & & 1,894 & 90,113 & 90,573 & 89,421 & & \\
\hline \multicolumn{12}{|l|}{ Age (years) } \\
\hline Mean [95\% Cl] & \multicolumn{5}{|c|}{$68.1\{63.5,72.8\}$} & \multicolumn{5}{|c|}{$50.7\{49.5,51.9\}$} & $<10-4$ \\
\hline Median [interquartile] & \multicolumn{5}{|c|}{$66.5\{55.4,73.3\}$} & \multicolumn{5}{|c|}{$51.7\{40.2,63.2\}$} & \\
\hline \multicolumn{12}{|l|}{ Sex } \\
\hline Male & 27 & 1,338 & 88 & 2,030 & 100 & 1,739 & 82,071 & 80,029 & 83,733 & 91.1 & 0.0007 \\
\hline Female & 0 & 0 & 0 & 0 & 0 & 155 & 8,041 & 6,380 & 10,084 & 8.9 & \\
\hline \multicolumn{12}{|l|}{ Disposition from ED^^} \\
\hline Release & 4 & 199 & 67 & 485 & 16 & 1,637 & 78,985 & 75,886 & 81,482 & 87.8 & 0.0018 \\
\hline Admit & 13 & 497 & 263 & 778 & 39 & 253 & 10,914 & 8,449 & 13,973 & 12.1 & \\
\hline Died & 9 & 572 & 301 & 867 & 45 & 1 & 77 & 9 & 621 & 0.1 & \\
\hline
\end{tabular}

TABLE 2: Patients with snowblower-associated events by the presence or absence of a cardiac event.

$\mathrm{n}=$ actual number of ED visits, $\mathrm{N}=$ estimated number of ED visits, $\mathrm{L} \%=$ lower $95 \%$ confidence interval of the estimate, $\mathrm{U} \%=$ upper $95 \%$ confidence interval of the estimate

\section{Injuries}

The five major injury diagnoses, when excluding medical events, were a fracture in $25.9 \%(23,134(19,614$ $27,038))$, a laceration in $20.2 \%(18,096(15,106-21,501))$, a strain/sprain in $15.0 \%(13,378(10,482-16,895))$, an amputation in $11.2 \%(9,990(7,102-13,300))$, and a contusion/abrasion in $10.2 \%(7,344(5,608-9,168))$. The anatomic locations of the five major injury diagnoses are shown in Figure 1; all the amputations occurred in the upper extremity. The estimated 9,990 amputations represent an actual $\mathrm{n}$ of 272; of these 272, 271 involved the fingers and one the hand. An amputation, fracture, or laceration accounted for 43,524 (47.6\%) of the 91,451 ED visits. Of these 43,524 visits, a fracture was the most common diagnosis when the injury involved the forearm or wrist, a laceration when the injury involved the hand, and fractures and amputations when the injury involved the fingers (Figure 2).

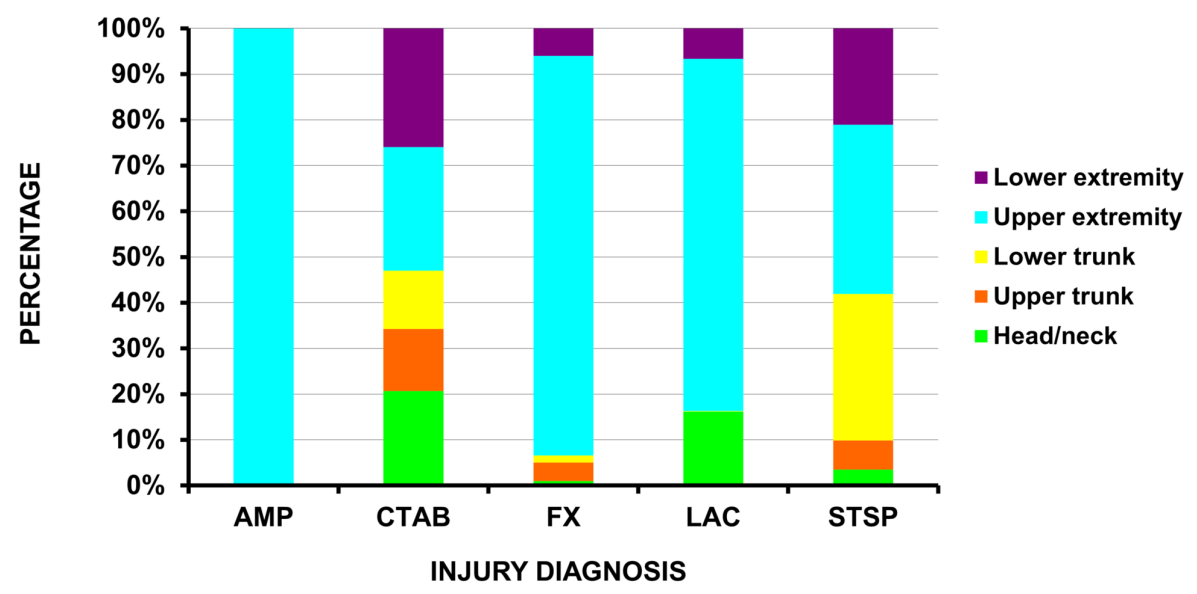

FIGURE 1: Injuries sustained from snow blowers

Anatomic location of the five major injury diagnoses sustained from snow blowers by body area

$\mathrm{AMP}=$ amputation, $\mathrm{CTAB}=$ contusion/abrasion, $\mathrm{FX}=$ fracture, $\mathrm{LAC}=$ laceration, $\mathrm{STSP}=$ strain/sprain 


\section{Cureus}

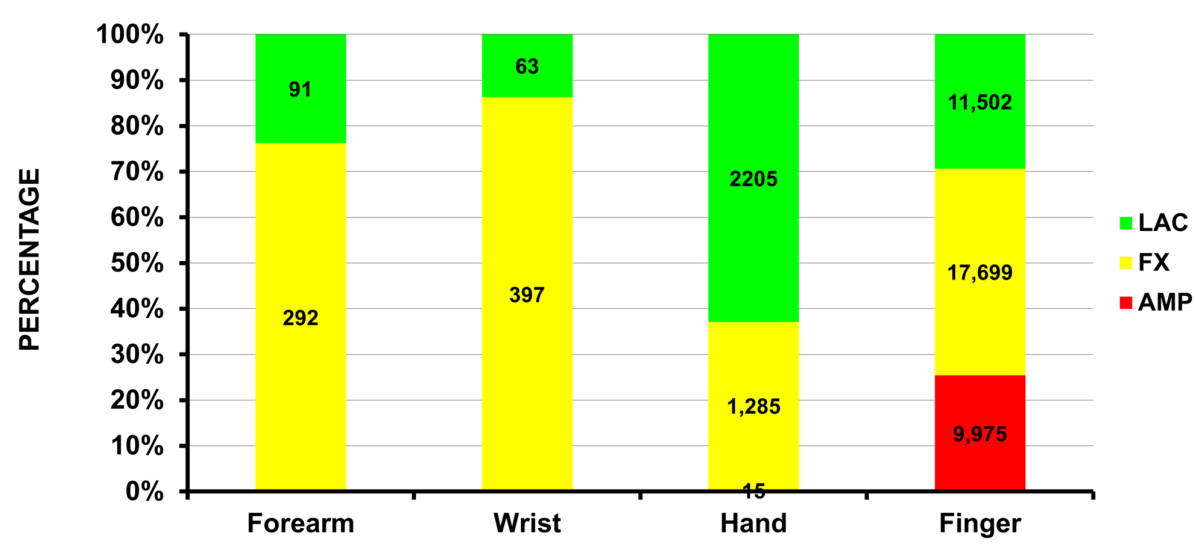

ANATOMIC LOCATION

\section{FIGURE 2: Injuries from snow blowers distal to the elbow}

The 43,524 injuries occurring distal to the elbow

These 43,524 patients accounted for $47.6 \%$ of all ED visits due to snow blowers.

Further analyses between those with or without an amputation (Table 3) demonstrated that those with amputations were $97 \%$ male and those without amputations were $90 \%$ male. Patients with amputations were more frequently admitted to the hospital (36.3\% vs $7.8 \%$ ). All who sustained an amputation had put their hand into the chute; however, of the 40,969 patients that placed their hand into the chute, only 9,990 (24.4\%) sustained an amputation. 


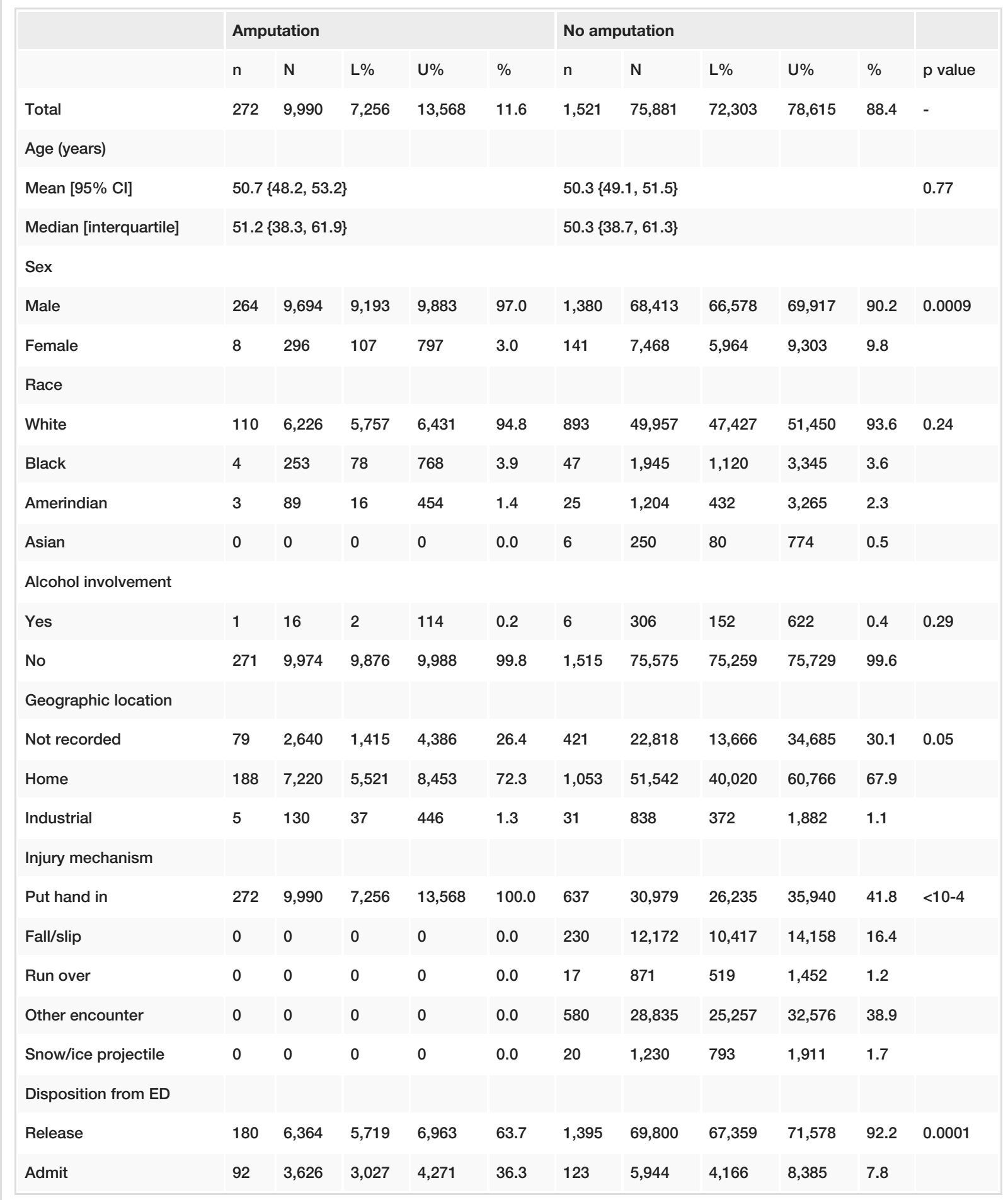

TABLE 3: Demographics of snowblower injuries (excluding medical events) by presence/absence of an amputation

$\mathrm{n}=$ actual number of ED visits, $\mathrm{N}=$ estimated number of ED visits, $L \%=$ lower $95 \%$ confidence interval of the estimate, $U \%=u p p e r 95 \%$ confidence interval of the estimate

\section{Temporal variations}

The ED visits peaked on January and February weekends (Figure 3). The average incidence of snowblower visits to EDs in the USA was 1.845 per 100,000 US population and did not change over time (Figure 4). There was a general correlation between the number of ED visits per year with the snow cover area that year [23] (Figure 5). The average incidence of ED visits was normalized by the average annual snow cover area in the 


\section{Cureus}

contiguous 48 US states, using data from the National Oceanic and Atmospheric Administration (Rutgers University Global Snow Laboratory) [23-24]. Even when correcting for the average annual snow cover area, there was no change in the incidence of snowblower injury ED visits over time.

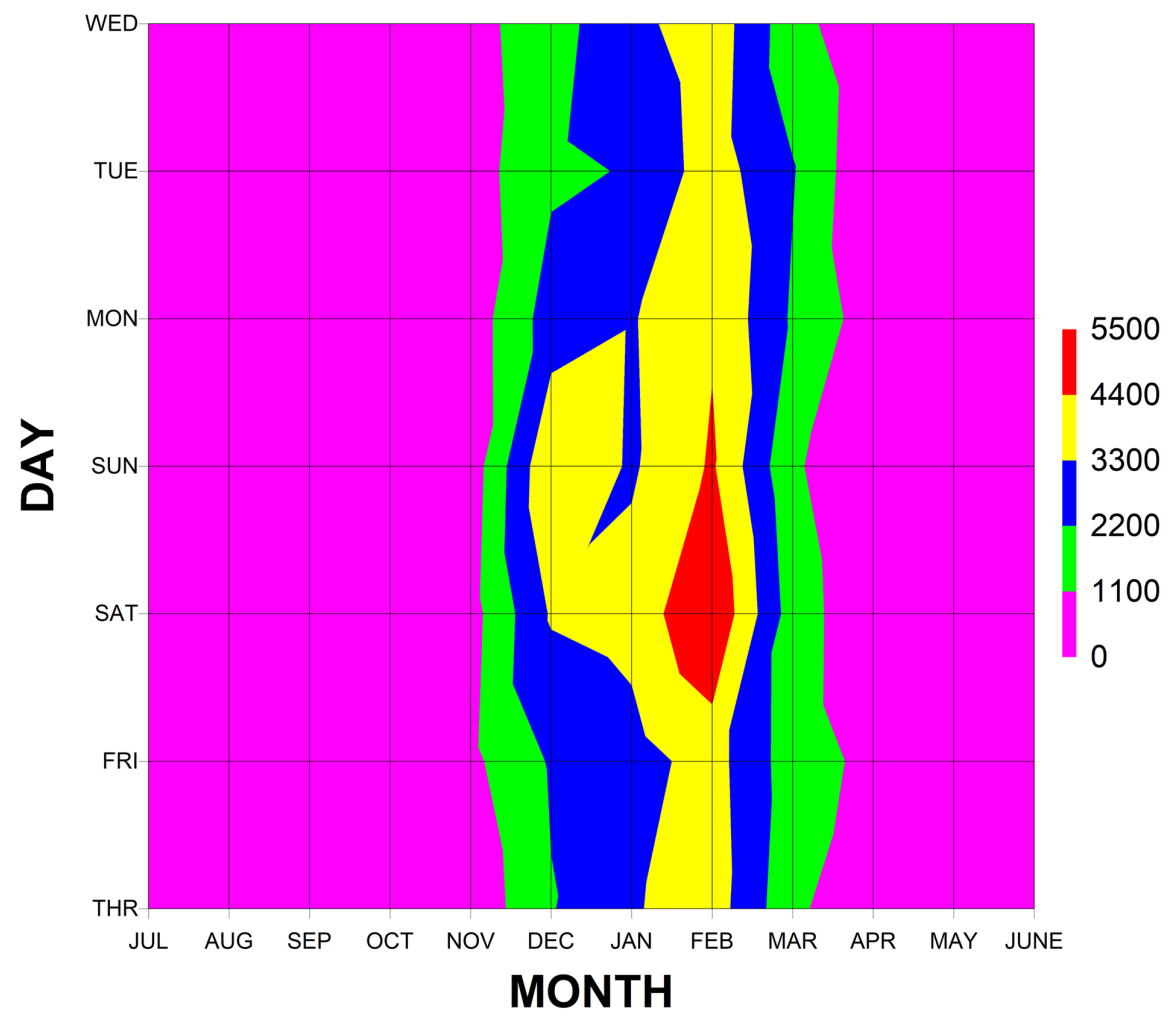

\section{FIGURE 3: Snowblower ED visits by month and weekday}

The number of emergency department (ED) visits by month and day of the week as demonstrated on a topographical projection

The peak occurred on Saturdays and Sundays from mid-January to mid-February.

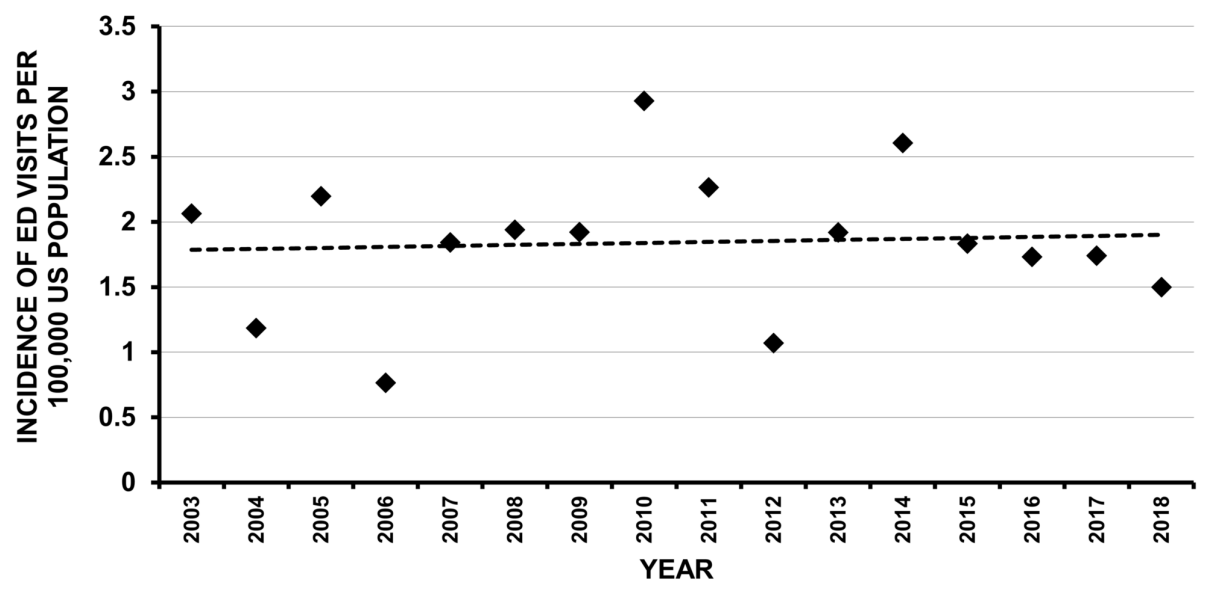

\section{FIGURE 4: Incidence over time}

The overall incidence was 1.845 per 100,000 US population and did not change over time $\left(r^{2}=0.005, p=\right.$ 0.81 ) (filled rhomboids represent the incidence for each year and the hatched line represents linear regression over time). 


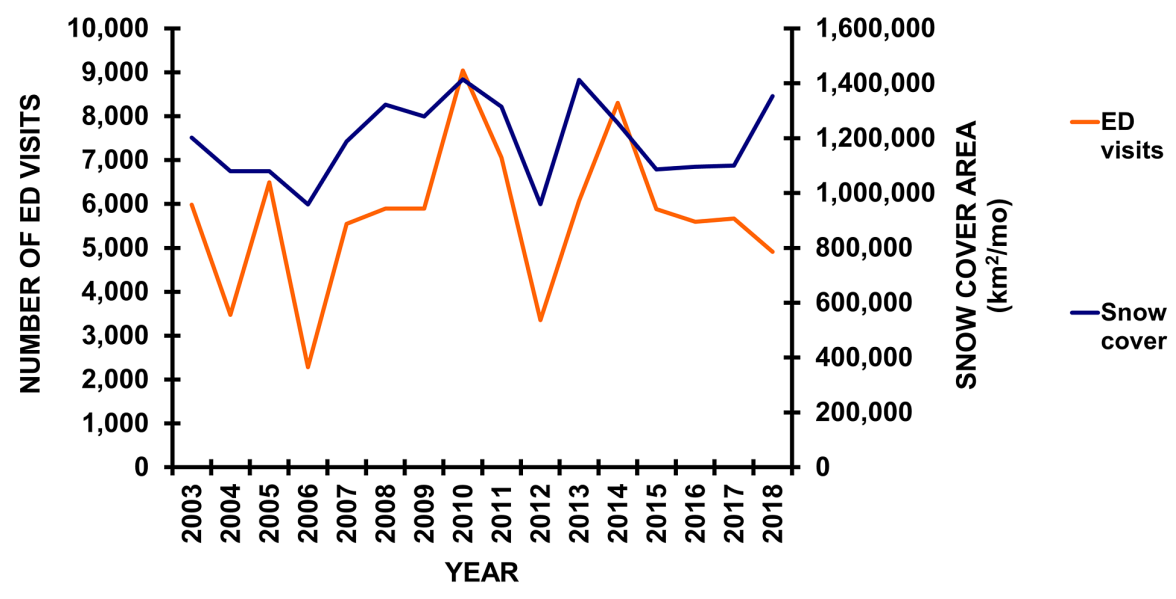

FIGURE 5: Snowblower ED visits per year and annual snow cover area

The number of ED visits per year (solid orange line) and the average annual snow cover $\left(\mathrm{km}^{2}\right)$ in the 48 contiguous states per year (solid blue line)

Snow cover data from Robinson [23] as described by Estilow [24]

\section{Discussion}

The overall prevalence of amputation for ED visits associated with snow blowers was 10.9\% (9,990 of 91,451 ED visits). Essentially, all of the amputations involved the digits. One study noted that $2.1 \%$ of snowblower hand injuries involved the thumb [8] while most others note no thumb amputations [1-2,5]. The exact location of the amputation and the involved digit is not systematically coded in NEISS data. The narrative comments could be used to ascertain such information, but this is likely not very accurate, as some coders may give information regarding the level of the amputation, involved digit, and level of amputation while others may not. For this reason, we did not review the narrative comments for the amputations and attempt to discern between right/left hand, finger/thumb, and level of amputation, as such data is likely incomplete and thus inaccurate.

We noted no overall change over time in the incidence of snowblower injury ED visits for the entire US population (Figure 4). Rubenstein et al. [11] noted an increase in snowblower-related hand injuries using the NEISS database for the years 2001 through 2016 when normalizing the incidence per inch of snowfall. When using the average annual snow cover area for all 48 contiguous states as a surrogate for snowfall, we did not find any change in the incidence over time. This is likely due to different ways of assessing snowfall between the two studies. Rubenstein et al. used the annual snowfall for each state's capital city or largest city [11]; we used the actual annual snow cover as determined by satellite imaging and did not find any change over time. However, the change noted by Rubenstein et al. was minimal [11], indicating that the results from both studies are very similar.

The finding that these injuries peaked in the winter months is not surprising. Seasonal trends in traumatic digit amputations have been previously described [12], with winter having the highest percentage of snowblower amputations in a study from the North Eastern United States (Rhode Island). Such percentages would likely differ depending on the geographic location of the study (eg. a study of amputations in the southern US would likely show different results, as snowblower activity is minimal there). Interestingly, there was also a peak on the weekends in this study. Snowfall is not prejudiced toward particular days of the week. This increase during weekend days likely reflects when the person responsible for snow removal has time to perform said job. This would likely mean at home. In this study, $68.9 \%$ of the events occurred at home, confirming this supposition.

A major finding of this study is that cardiac events can be associated with the use of snow blowers. Shoveling snow is well-known to be associated with major cardiac events [14-21]. A previous study of 36 snow removal cardiac-related events in the Detroit metropolitan area found that four were associated with snow blowers and 32 with snow shoveling [19]. We have more formally described the association of cardiac events with snow blowers at the national level. Such a finding was unexpected, as one goal of a snow blower is to reduce the physical exertion needed for snow removal $[1,9,17,20]$. The narrative comments of all 27 patients with cardiac events were reviewed; snow shoveling was not mentioned in any of them. One case noted that strenuous activity had been performed along with the snowblower activity, and another noted that the patient was pushing the snow blower through the snow. These are strenuous events and perhaps precipitated the cardiac event [16]. It is possible that these patients using snow blowers were also using a snow shovel to 
remove snow from those areas not amenable to the snow blower. However, this is conjecture, as none of the narrative comments mentioned such activity. All of the patients with cardiac events were male; male preponderance with cardiac events and snow shoveling has been noted by others [14-15,18].

Alcohol use was noted in $0.4 \%$ of snowblower-associated events but could be greater if such cases were not noted in the narrative comments. This $0.4 \%$ is less than that for many recreational activities occurring in the autumn/winter months. For traditional winter sports of skiing and snowboarding, alcohol involvement is $2.1 \%$ [25]. However, in one study of Austrian skiers, it was $30.0 \%$ for males and $16 \%$ for females [26]. In a British study of skiers admitted for the care of an injury compared to a non-injured cohort [27], injury was 7.1 times more common in those with alcohol consumption. Hunting, which occurs in the late autumn and early winter, has a $1.5 \%$ prevalence of alcohol use [28] and $2.4 \%$ when a hunter falls from a hunting stand [29].

\section{Limitations}

Large data sets inherently possess some inaccuracy. However, the NEISS data collection protocols have $89 \%$ 98\% accuracy [30]. Second, the NEISS only captures those who sought care in the ED; those seeking care in physician's offices or urgent care centers are not captured. This might apply to minor sprains, contusions, but the more severe open injuries, medical events, and fractures are likely captured. This, of course, decreases the number of patients and might skew the results regarding the demographics and types of injuries. Details of the amputations such as the level of the finger amputation (tuft, joint/phalanx level), laterality, and finger versus thumb are not coded in the NEISS data set. Finally, the percentage of amputations described in this study only reflects the immediate number; it is possible that secondary amputations were performed after the initial ED visit. The magnitude of this is unknown.

\section{Conclusions}

This study has characterized the demographics and associated injury patterns associated with snowblower use in patients presenting to US emergency departments. The average annual incidence of ED visits for snowblower-associated events was 1.85 per 100,000 US population and did not change from 2003 through 2018. Of the 91,451 estimated ED visits for snowblower-associated events, 9,990 (10.9\%) sustained an acute amputation and 5,580 (6.1\%) a medical event, with $1.5 \%$ a cardiac event (1,378 of 91,451). ED mortality for the cardiac events was $45 \%$. For the non-medical events, the most common diagnoses were a fracture in $25.3 \%$, laceration in $20.0 \%$, strain/sprain in $14.8 \%$, amputation in $10.9 \%$, and contusion/abrasion in $8.1 \%$. Opportunity still exists for prevention, as there was no real change in the incidence of these injuries over this 16-year time span.

\section{Additional Information \\ Disclosures}

Human subjects: Consent was obtained by all participants in this study. Human Subjects Office, Office of Research Compliance - Indiana University issued approval 1805750391. This study was considered to be exempt by our Institutional Review Board, Indiana University, study number 1805750391. Animal subjects: All authors have confirmed that this study did not involve animal subjects or tissue. Conflicts of interest: In compliance with the ICMJE uniform disclosure form, all authors declare the following: Payment/services info: All authors have declared that no financial support was received from any organization for the submitted work. Financial relationships: All authors have declared that they have no financial relationships at present or within the previous three years with any organizations that might have an interest in the submitted work. Other relationships: All authors have declared that there are no other relationships or activities that could appear to have influenced the submitted work.

\section{Acknowledgements}

This research was supported in part by the Garceau Professorship Endowment, Indiana University, Department of Orthopaedic Surgery, and the Rapp Pediatric Orthopaedic Research Endowment, Riley Children's Foundation, Indianapolis, Indiana.

\section{References}

1. Almdahl SM, Sæbøe-Larsen J, Jan D Jr: Injuries to the hand inflicted by rotary snowcutters . J Trauma. 1989, 29:227-228. 10.1097/00005373-198902000-00014

2. Istre GR, Tinnell C, Ouimette D, Gunn RA, Shillam P, Smith GS, Hopkins R: Surveillance for injuries: cluster of finger amputations from snowblowers. Public Health Rep. 1989, 104:155-157.

3. Hammig B, Jones C: Injuries related to snow blowers in the United States: 2002 through 2008. Acad Emerg Med. 2010, 17:566-569. 10.1111/j.1553-2712.2010.00730.x

4. Hammig B, Jones C: Hand injuries associated with reaching into a snow blower to clear clogged snow . Am J Emerg Med. 2020, 38:785-788. 10.1016/j.ajem.2019.06.042

5. Millea TP, Hansen RN: Snowblower injuries to the hand. J Trauma. 1989, 29:229-233. 10.1097/00005373198902000-00015

6. Center for Disease Control: Snow-blower injuries--Colorado, New York. MMWR Morb Mortal Wkly Rep. 
1983, 32:77-78

7. Proano L, Partridge R: Descriptive epidemiology of a cluster of hand injuries from snowblowers . J Emerg Med. 2002, 22:341-344. 10.1016/s0736-4679(02)00451-1

8. Chin G, Weinzweig N, Weinzweig J, Geldner P, Gonzalez M: Snowblower injuries to the hand . Ann Plast Surg. 1998, 41:390-396. 10.1097/00000637-199810000-00007

9. Waller JA: Snowblower injuries. J Trauma. 1977, 17:122-125. 10.1097/00005373-197702000-00006

10. Master D, Piorkowski J, Zani S, Babigian A: Snowblower injuries to the hand: epidemiology, patterns of injury, and strategies for prevention. Ann Plast Surg. 2008, 61:613-617. 10.1097/SAP.0b013e318166dafe

11. Rubinstein AJ, Thomson JE, Siracuse BL, DeCotiis MR, Ahmed IH, Vosbikian MM: The incidence of snow blower-related injuries to the hand in the United States. Ann Plast Surg. 2019, 82:393-398. 10.1097/SAP.0000000000001747

12. Harris AP, Goodman AD, Kuczmarski AS, Gil JA, Katarincic JA: Seasonal trends in traumatic digit amputations: experience of a level 1 and level II hospital in a Northeastern state. Hand. 2019, [Epub]:10.1177/1558944719844347

13. Tetz DJ, Aghababian R: Hand injuries from snow blowers: a report of an epidemic . Prehospital Disaster Med. 1995, 10:265-267. 10.1017/s1049023x0004214x

14. Auger N, Potter BJ, Smargiassi A, Bilodeau-Bertrand M, Clément Paris, Kosatsky T: Association between quantity and duration of snowfall and risk of myocardial infarction. Can Med Assoc J. 2017, 189:235-242. 10.1503/cmaj.161064

15. Nichols RB, McIntyre WF, Chan S, Scogstad-Stubbs D, Hopman WM, Baranchuk A: Snow-shoveling and the risk of acute coronary syndromes. Clin Res Cardiol. 2012, 101:11-15. 10.1007/s00392-011-0356-6

16. Franklin BA, Bonzheim K, Gordon S, Timmis GC: Snow shoveling: a trigger for acute myocardial infarction and sudden coronary death. Am J Cardiol. 1996, 77:855-858. 10.1016/S0002-9149(97)89181-3

17. Franklin BA, Hogan P, Bonzheim K, Bakalyar D, Terrien E, Gordon S, Timmis GC: Cardiac demands of heavy snow shoveling. JAMA. 1995, 273:880-992. 10.1001/jama.1995.03520350062030

18. Sauter T, Haider DG, Ricklin ME, Exadaktylos AK: The snow, the men, the shovel, the risk? ER admissions after snow shovelling: 13 winters in Bern. Swiss Med Wkly. 2015, 145:14104. 10.4414/smw.2015.14104

19. Chowdhury PS, Franklin BA, Boura JA, et al.: Sudden cardiac death after manual or automated snow removal . Am J Cardiol. 2003, 92:833-835. 10.1016/s0002-9149(03)00894-4

20. Womack CJ, Paton CM, Coughlin AM, Nagelkirk PR, Dejong AT, Anderson J, Franklin BA: Coagulation and fibrinolytic responses to manual versus automated snow removal. Med Sci Sports Exerc. 2003, 35:1755-1759. 10.1249/01.MSS.0000089254.78325.57

21. Watson DS, Shields BJ, Smith GA: Snow shovel-related injuries and medical emergencies treated in US EDs, 1990 to 2006. Am J Emerg Med. 2011, 29:11-17. 10.1016/j.ajem.2009.07.003

22. Eveleth PB, Tanner JM: Worldwide Variation in Human Growth. Cambridge University Press, Cambridge, England; 1990

23. National Oceanic and Atmospheric Administration, Department of Commerce NOAA climate data record (CDR) of northern hemisphere (NH) snow cover extent (SCE), version 1. (2020). Accessed: April 23, 2020: https://catalog.data.gov/dataset/noaa-climate-data-record-cdr-of-northern-hemisphere-nh-snow-coverextent-sce-version-1.

24. Estilow TW, Young AH, Robinson DA: A long-term northern hemisphere snow cover extent data record for climate studies and monitoring. Earth Syst Sci Data. 2015, 7:137-142. 10.5194/essd-7-137-2015

25. Basques BA, Gardner EC, Samuel AM, Webb ML, Lukasiewicz AM, Bohl DD, Grauer JN: Injury patterns and risk factors for orthopaedic trauma from snowboarding and skiing: a national perspective. Knee Surg Sports Traumatol Arthrosc. 2018, 26:1916-2016. 10.1007/s00167-016-4137-7

26. Menz V, Philippe M, Pocecco E, Ruedl G, Woldrich T, Sommersacher R, Burtscher M: The use of medication and alcohol in recreational downhill skiers: results of a survey including 816 subjects in Tyrol. J Sci Med Sport. 2019, 22:22-26. 10.1016/j.jsams.2019.04.014

27. Hasler RM, Dubler S, Menneker LM, et al.: Are there risk factors in alpine skiing? A controlled multicentre survey of 1278 skiers. Br J Sports Med. 2009, 43:1020-1025. 10.1136/bjsm.2009.064741

28. Loder RT, Farren N: Injuries from firearms in hunting activities . Injury. 2014, 45:1207-1214. 10.1016/j.injury.2014.04.043

29. Loder RT: Epidemiology of hunting standing injuries presenting to US emergency departments, 2008-2013. Wilderness Env Med. 2015, 26:68-75. 10.1016/j.wem.2014.07.004

30. Annest JL, Mercy JA, Gibson DR, Ryan GW: National estimates of nonfatal firearm-related injuries. Beyond the tip of the iceberg. JAMA. 1995, 273:1749-1754. 10.1001/jama.1995.03520460031030 